\title{
ELES, OS DESGRAÇADOS! OU MANIFESTO PARA PENSAR UM CURRÍCULO AMOROSO
}

\author{
Lêda Valéria Alves da SILVA \\ Sílvia Nogueira CHAVES ${ }^{\text {ii }}$
}

\begin{abstract}
RESUMO
Neste texto manifesto, defende-se a ideia de que é possível pensar sobre um currículo para a Educação Ambiental que pense um currículo amoroso, encaminhe para outros movimentos, tirando da paralisia que gera apenas reclamações e palavras de ordem para o homem; um currículo que crie forças ativas contra as forças reativas. Pretende-se exercitar uma aproximação entre os conceitos de resistência (Antônio Negri) e de linhas de fuga (Gilles Deleuze), com o intuito de refletir sobre aquele currículo para a Educação Ambiental como resistência por meio daquelas vidas vistas como "menores", "inúteis". Assim, o que se deseja é inventar; pensar linhas de fuga; romper as linhas clássicas inscritas no currículo sendimentarizado. Talvez seja o momento de pensar no amor como um espaço de criação e resistência para imaginar outra Educação Ambiental. Pensar uma Educação Ambiental que potencialize a experiência e a vida. Criar linhas de fuga através das existências supostamente infames, buscando outras formas de existir e de agir quando se fala no ambiente. A ideia não é mudar os paradigmas, mas sair deles.
\end{abstract}

PALAVRAS-CHAVE: Currículo; Educação Ambiental; Resistência; Linhas de fuga; Amor.

\section{THEY, THE BASTARDS! OR MANIFEST TO THINK OF A LOVING CURRICULUM}

\begin{abstract}
In this manifesto we defend the idea that it is possible to think about a curriculum for Environmental Education that goes beyond, that throws us to other movements, that takes us out of paralysis, that only makes complain and shout slogans for man, but that create forces active against reactive forces. The idea is to do a conceptual approximation exercise between Antonio Negri concepts of resistance and Gilles Deleuze escape lines to think of a curriculum for Environmental Education as resistance through those lives that we look to be smaller, useless. So what we want is to invent; think of trailing lines; crack the classic lines inscribed in the sendimentalized curriculum. Perhaps it is time to think of love as a space of creation and resistance to imagine another environmental education. Think of an environmental education that enhances experience, life. Create escape lines across the ocean, looking for other ways to exist, to act when talking about the environment. The idea is not to change paradigms, but to get out of them.
\end{abstract}

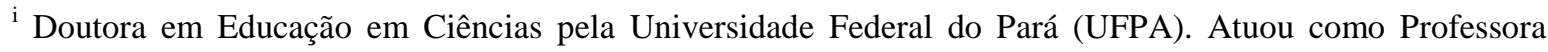
Substituta na UFPA de 2012 a 2014. E-mail: leda_valeria@yahoo.com.br.

ii Doutora em Educação pela Universidade Estadual de Campinas (Unicamp). Coordena o Grupo de Estudos e Pesquisa Cultura e Subjetividade na Educação em Ciências, do Programa de Pós-Graduação em Educação em Ciências e Matemáticas (PPGECM/UFPA), no qual é docente. Atua como editora da Revista Experimentart. É associada à Universidade Livre de Autobiografia de Anghiari, Itália. E-mail: snchaves@ yahoo.com.br. 
KEYWORDS: Curriculum; Environmental education; Resistance; Escape lines; Love.

\title{
LOS BASTARDOS! O MANIFIESTO PARA PENSAR EM UM CURRÍCULUM AMOROSO
}

\begin{abstract}
RESUMEN
En este manifiesto defendemos la idea de que es posible pensar en un plan de estudios para la Educación Ambiental que vaya más allá, que nos arroje a otros movimientos, que nos saque de la parálisis, que solo haga quejarse y gritar consignas para el hombre, pero que cree fuerzas activo contra fuerzas reactivas. La idea es hacer un ejercicio de aproximación conceptual entre los conceptos de resistencia de Antonio Negri y las líneas de escape de Gilles Deleuze para pensar en un plan de estudios para la Educación Ambiental como resistencia a través de esas vidas que vemos como más pequeñas e inútiles. Entonces, lo que queremos es inventar; piense en las líneas finales; descifrar las líneas clásicas inscritas en el currículum sentimental. Quizás sea hora de pensar en el amor como un espacio de creación y resistencia para imaginar otra educación ambiental. Piense en una educación ambiental que mejore la experiencia, la vida. Cree líneas de escape a través del océano, buscando otras formas de existir, para actuar cuando se habla del medio ambiente. La idea no es cambiar los paradigmas, sino salir de ellos.
\end{abstract}

PALABRAS CLAVE: Plan de estudios; Educación ambiental; Resistencia; Líneas de escape; Amor

\section{POR QUE FALAR EM "BICHOS ESCROTOS" PARA FALAR DE CURRÍCULO?}

"Bichos saiam dos lixos Baratas me deixem ver suas patas

Ratos entrem nos sapatos

Do cidadão civilizado"

(Sérgio Affonso/Nando Reis/Arnaldo Antunes. Bichos escrotos)

Ser rato na feira é dureza, ainda mais quando tem urubu sobrevoando a carniça. Pesa na lembrança a imagem de um rato agonizando próximo à vala depois de ser abatido, provavelmente a pauladas. Em seu corpo, as escoriações eram visíveis. Adiante, um urubu é enxotado depois de pousar sobre restos de peixes, descartados depois da separação do filé.

Em seguida, observando uma barata tonta, nota-se que a baforada baygonica fora pouco para a matar, o que a fez passear por entre pés afoitos para pisoteá-la até ver a sangria branca escorrer no chão. Estas imagens, infelizmente, não comovem as pessoas, a não ser pelo nojo que lhes causam. Por outro lado, seria possível pensar: Eles só querem 
comer! Eles só querem viver! Mesmo que o pensamento não seja privilégio de todo vivente, trata-se daquilo que todos desejam, afinal... Mas esse tipo de empatia não interessa àqueles. Quem quer conviver com os "bichos escrotos"? Tentar silenciar aquilo que incomoda é senso comum... Matá-los protege o homem do suposto caos.

Suas vidas, desnecessárias, são rifadas a cada instante. Clandestinos, sabem que é preciso esperteza, sob o peso de a vida ser efêmera. Morrem sob o atrito de um reles chinelo. Esses bichos são considerados desgraçados, perigosos, astutos, transmissores de doença, certamente. "Pragas urbanas"! Animais que não devem se "encarar", a não ser para a eliminação. Mas eles não parecem temer, conhecem a cidade como ninguém. Apesar da iminência da morte, eles resistem! Imiscuem-se nas fendas dos matos, empoleiram-se nas árvores, deslocam-se nas rachaduras... Vivem o fluxo em suas variadas formas, numa impermanência tamanha que não se ousa descrever.

Diverge-se dessas vidas e se lhes nega os enfrentamentos, ainda que bobos, como mirar nos olhos de uma barata. Ligeiramente, esgueira-se para não os ver. Não se vê alegria no combate. Ela encara o homem, teimosa, espera alguns segundos e foge, entrando em um buraco qualquer, numa quietude que ele não cultiva, possivelmente, por causa do medo. Trata-se de um modo de viver muito sofisticado este que afronta a vida (encara) e, ao mesmo tempo, evita a morte (foge). Como o soldado descrito por Zizek (2002) que "cercado de inimigos, se tiver de abrir caminho, precisa combinar um forte desejo de viver com uma estranha despreocupação com a morte" (p.39). Não existe no homem o desejo do combate, tampouco o germe de um novo modo de existência, como pensou Deleuze (2013). É desgraça demais... Barata, rato, germe...!!

Há avidez por matar, mas não aquilo que separou a vida do que ela pode. A intensidade humana foi capturada, entristecida; tornou-se lamurienta. Segue-se a (des)qualificação de outros modos de vida, como se todos fossem os mesmos. Não se admitem outras vidas que não sejam tributárias das vivências humanas. Hardt e Negri (2012) afirmam que as armadilhas biopolíticas buscam a todo o momento encurralar a multidão dos marginais para os transformar em corpos empilhados. Uma massa indistinguível e desvanecida. Enfim, silenciosa. A vontade de unidade pode ser, justamente, o que nos faz seres infinitamente menos resistentes do que as baratas, pois com essa união 
nos tornamos previsíveis e vulneráveis, como árvores fincadas na floresta.

Mas a multidão de desgraçados desafia, mantém firme sua singularidade, sua diversidade, desliza no chão. Essa multidão é movente e rizomática. Não se pode capturar diferentes maneiras de viver. Diferente da massa, que é una e facilmente capturável, a multidão "possui inúmeras diferenças internas, (...) diferentes maneiras de viver; diferentes visões de mundo" (HARDT E NEGRI, 2012, p. 12). Isto é incômodo, porque o modo de vida difuso não obedece a parâmetros ou referências, devendo por isso ser combatido e, de preferência, extinto. Seria um ambientalismo seletivo.

Como se pode pensar então em uma vida intensa? Uma vida que encara e, ao mesmo tempo, foge ao que acontece? O que acontece é que esses desgraçados não são trapaceiros. Eles investem numa postura de resistência que os fortalece. Eles não têm a diferença submetida a uma forma ou uma identidade. Esses seres minúsculos não estão apenas facilitando a maneira de agir, eles estão resistindo ao poder com o corpo, com a vida. Eles encontraram o ponto cego no qual a vida não é administrada ou controlada. Não estão submetidos aos códigos de uma sociedade e fogem deles, criam suas linhas de fuga e, mesmo que a territorialidade insista em fixá-los, eles também escapam. As linhas então "nos compõem [...]. Elas se transformam e podem mesmo penetrar uma na outra" (DELEUZE; GUATTARI, 2012, p. 84).

A linha de fuga, como pensada por Deleuze (1998) é um movimento de “desterritorialização", de fuga, mas "fugir não é renunciar às ações, nada mais ativo que uma fuga. É o contrário do imaginário. É também fazer fugir, não necessariamente os outros, mas fazer alguma coisa fugir, fazer um sistema vazar como se fura um cano" (p. 49). Criar uma linha de fuga é criar e agir contra um pensamento dogmático. Assim, Deleuze sustenta que uma "linha de fuga" nunca consiste em fugir do mundo, mas em causar escoamentos... Nunca se sabe ao certo em que ponto uma linha de fuga vai fissurar ou escoar, porque não é linear.

Acredita-se que é possível refletir sobre um currículo para a Educação Ambiental que extravase o pensamento, que direcione para outros movimentos, tirando da paralisia que gera apenas reclamações e palavras de ordem para o homem; um currículo que crie forças ativas contra as forças reativas (NIETZSCHE, 2004). Quando se concede vazão às forças ativas, resiste-se e possibilidades de existência são criadas a partir de composições 
com forças inéditas, contrariando a "lógica" da reação costumeira que responde ao poder. Dessa forma, resistir é justamente o oposto de reagir (MACIEL JUNIOR, 2014). No livro “Kairos, Venus, Multitudo", Antônio Negri apresenta uma ideia de Resistência que não é mais aquela dos protestos e dos panfletos, mas uma resistência da fuga, do improvável, da deserção silenciosa.

[...] o conceito de "resistência" mudou, como se transformaram suas práticas! Se tentássemos identificá-lo de acordo com as categorias e as experiências do moderno, seríamos, agora, incapazes de compreendê-lo. No moderno, a resistência é um acúmulo de força contra a exploração, que se subjetiviza mediante a "tomada de consciência". No pós-moderno não é nada disso. A resistência se dá como difusão de comportamentos resistentes singulares. Acumulando-se, acumula-se extensivamente, na circulação, na mobilidade, na fuga, no êxodo, na deserção - multidões que, difusamente, resistem, que fogem das grades, cada vez mais estreitas, da miséria e do comando. E não é necessária a tomada de consciência coletiva: o sentido da rebelião é endêmico, atravessa cada consciência, tornando-a feroz. [...] Assim, a rebelião não se pontualiza nem se uniformiza, mas corre sobre os espaços do comum e se difunde como onilateralidade irrefreável dos comportamentos das singularidades. Assim se define a resistência da multidão (NEGRI, 2003, p. 129 e 130).

Nesse sentido, resistir parece ser da ordem da experimentação e, como tal, não tem ponto de chegada, tampouco uma única direção, porque experimentar é estar aberto aos fluxos, às passagens e ao que nos atravessa. Como fazem as "pragas", experimentar movimentos de desterritorialização de si mesmo. Então, como elaborar um currículo que perambule junto à potência de vida dos animais considerados perigosos, pragas, marginais? Como traçar linhas para um currículo que pense a vida como "obra de arte", como ética para existência?

Este texto possui o intuito de aproximar os conceitos de resistência de Negri (2003) e os de linhas de fuga de Deleuze (1998) para refletir sobre um currículo para a Educação Ambiental como resistência por meio daquelas vidas que são percebidas como menores, inúteis em relação à humana, como as baratas, os ratos, os matos... ignorados nas Diretrizes Curriculares Nacionais para a Educação Ambiental. Contudo, não se trata de mudar o currículo, mas o tornar diferente, pensar e agir de forma diversa; experimentar mutações que possam tornar-se defesas contra os venenos que rodeiam a sociedade. Assim, o que se deseja é inventar outros modos de ver; pensar linhas de fuga; subverter as linhas clássicas 
inscritas no currículo sedimentado tal como já foi pensado por Corazza e Silva (2003); Paraíso (2009).

Inventar um devir - resistência dos desgraçados - para o currículo ambiental. Um currículo no entre, nas fissuras, nas fendas pelas quais fogem os "desgraçados" indivíduos, tal como queriam Deleuze e Guatarri (2007). "Desta forma, essas aventuras do pensamento nos parecem ser cativantes em oposição ao cativeiro do pensamento único que sorve nossas forças e despende nosso tempo" (SANTOS, 2014).

Este texto divide-se em três partes. Na primeira parte, discute-se a ideia de "currículo - inseticida", que entope os poros dos alunos a ponto de transformá-los em seres atordoados e fáceis de interpelar; na segunda parte, aborda-se um devir - resistência, que não se ressente do inseticida, mas inventa caminhos para criar outras formas de vida, antídotos nesta vida; na terceira parte, ensaia-se a criação de um "antídoto", uma resistência periférica, menor, que pense o currículo para uma Educação Ambiental amorosa como abertura para o mundo.

Então, faz-se um convite à experimentação de uma nova ética para o currículo para Educação Ambiental, que não seja mais aquela do direito (do bem e do mal), mas a que faz aparecer modos de vida que não renunciam ao mundo ou aos encontros e que modulam, de modo diverso, a relação com os outros pelo cuidado de si sem disciplina e constrangimento (RAGO, 2009). Transitar por entre frestas e resistir como multidão àquilo que submete a vida aos inseticidas e aos arranques. Proliferar, enfim, currículos que expressem a diferença ao invés da mesmidade.

\section{CURRÍCULO - INSETICIDA}

Ratos, baratas, urubus, pombos estão nas ruas, nas casas e em toda parte. Vivendo nelas. Desafiando e ameaçando a vida (?) das pessoas. Nessa sociedade do controle, em que tudo tem de ser massificado para ser supostamente produtivo, esses miseráveis caminham para o extermínio. As relações de poder produzem os supostos desviantes (ratos, baratas etc), as formas de controlá-los (dedetização) e de mantê-los à distância (inseticidas, venenos etc). Assim, compra-se a pretensa segurança nas prateleiras dos supermercados e farmácias, estando à disposição para quando esses desviantes aparecerem aos olhos. 
Nossos "bichos escrotos" são interpelados pelo poder. Carregam uma existência de pauladas e pisoteios. Seus corpos são desenhados, monitorados e, porque não dizer, produzidos para causar nojo e repugnância. Eles são fabricados para causar medo. Medo que atravessa os modos de subjetivação facilitando o controle de bom grado da própria vida. A existência desses seres mostra a insegurança diante daquilo que foge à regra, daquilo que não se consegue domesticar. Não é isso que o currículo faz? Não é isso que é feito com o currículo? Calam-se os modos de existência que não estão em conformidade com a dita "normalidade". Não é isso que é feito ao se inventar um currículo para a Educação Ambiental que conforma o homem a uma dita "consciência", que supostamente fará dele um Homo ambientalis, sob pena de não existir futuro para as "próximas gerações"?

Um currículo voltado para Educação Ambiental, além de "documento de identidade", como ensinou Silva (2005), é também um dispositivo de controle (de pragas!). Ele gerencia o conteúdo escolar e vigia os mal-intencionados, principalmente aqueles que pisam na grama e usam canudinho de plástico. Tema incômodo para a sociedade. Ironicamente, aquilo que serviria para "trazer à luz" aos indivíduos também é aquilo que os neutraliza. Esse controle abafa suas as linhas de fuga e interrompe seus movimentos de desterritorialização. Não se desconfia disso? Ao que parece, não! Sentem-se seguros tendo suas mentes borrifadas por aquilo que se chama de consciência ambiental, mesmo que ela os sufoque e importe mais do que a própria vida.

“Esses alunos não podem fazer o que querem!”, diriam os fabricantes dos inseticidas, mas a pergunta é: alguém sabe o que é querer em um mundo onde se consome experiência? Onde o "eu quero" já é uma imposição, uma captura (PARAÍSO, 2010)? O inseticida cumpre um papel importante: mantém os homens alheios aos pensamentos que são possíveis sobre eles mesmos. Um remédio prático e eficiente contra a heterogeneidade, pois atônitos eles podem ser agrupados, sem risco de questionar a forma e o conteúdo. "Este é um mundo que te domestica para que desconfies do próximo, para que seja uma ameaça e nunca uma promessa. É alguém que vai te fazer dano e, para isso, é preciso defender-se" (GALEANO, 2012).

Esse adestramento reativo inviabiliza a experiência, tirando da vida a capacidade de 
fabricá-la. Infelizmente, o que se denomina de experimentar é consumir referências, autorizações. Faça isso, não faça aquilo! Experimenta-se para enriquecer e perde-se a potência. Ela é sempre fraudada, inviabilizada e no lugar é posto o que se passa. O currículo pensado para a Educação Ambiental faz isso; entope o corpo, o pensamento e a vida. O que era para ser rico, torna-se mor(t)al. Segue-se nessa relação, pois a morte é lenta em vida.

Pode ser ruim e perigoso ir ao encontro do que inviabiliza o homem, pois talvez seja mais fácil viver regulado, ou seja, em suposta paz, a pensar sobre currículo e vida. A paz, nesse caso, é a possibilidade de ser preenchido e bestializado. Veja-se o exemplo do clipe da música Another Brick In The Wall, do Pink Floyd. "No fim, você é apenas outro tijolo no muro" ou a argamassa que preenche os vazios. E, quando preenchem os vazios, tornamse sem graça, sem força, sem vida.

Mas não há muros sem brechas ou que não sejam passíveis de fissura. Um currículo, seja ele qual for, também deixa alguns vazios entre os tijolos, rachaduras nos canos, pois

não há currículo que, nas bordas das individuações, não se dedique aos anômalos nem deixe de se opor às normalidades. Não há um, que não fissure os padrões, reconhecimentos, recognições. Não há currículo que imagine e acate só identidades majoritárias (CORAZZA, 2012, p. 12).

Não há currículo que seja inabalável. Afinal, os muros, mesmo os mais fortes, não resistem à multidão extasiada. Quanto mais se fabricam inseticidas, ainda os mais potentes, mais os "desgraçados" resistem. Eles têm estratégias muito peculiares. O veneno não é páreo para eles. Humanamente, poderia dizer que eles sobrevivem... será? "E se somente estivermos realmente vivos se nos comprometermos com uma intensidade excessiva"? (ZIZEK, 2003, p. 112).

Esses habitantes das cidades afirmam sua diferença, efetuam sua própria potência. Mais uma vez se pergunta a partir do questionamento feito por Zizek (2002): "Não seria o encontro com aquilo que tememos o fato de, finalmente, alguma coisa realmente acontecer a nós?" Será que esses encontros não seriam um (re)encontro com o acontecimento, com a experimentação, com a capacidade de desviar e fugir? Viver no lugar de sobreviver?

\section{DEVIR - RESISTÊNCIA}


Vê-se, raramente, um suposto desgraçado protestar. Provável que esteja fazendo qualquer outra coisa de sua vida enquanto palavras de ordem são ditas e frustrações alardeadas por meio da Educação Ambiental. Há nisso erro ou equívoco? Talvez, se essa for a mesma estratégia daqueles aos quais supostamente se opõem. Move-se da mesma maneira e usando os mesmos artefatos reativos dos ditos "opressores": o bem maior ou de todos, como se costuma dizer. Nietzsche já alertava para aquilo que se denomina de "reação à opressão", pois a ovelha não quer conviver com a ave de rapina, ela quer um ajuste, uma mudança de comportamento.

Que as ovelhas tenham rancor às grandes aves de rapina não surpreende: mas não é motivo para censurar às aves de rapina o fato de pegarem as ovelhinhas. E se as ovelhas dizem entre si: "essas aves de rapina são más; e quem for o menos possível ave de rapina, e sim o seu oposto, ovelha este não deveria ser bom?", não há o que objetar a esse modo de erigir um ideal, exceto talvez que as aves de rapina assistirão a isso com ar zombeteiro, e dirão para si mesmas: "nós nada temos contra essas boas ovelhas, pelo contrário, nós as amamos: nada mais delicioso do que uma tenra ovelhinha". - Exigir da força que não se expresse como força, que não seja um querer-dominar, um querer-vencer, um querer-subjugar, uma sede de inimigos, resistências e triunfos, é tão absurdo quanto exigir da fraqueza que se expresse como força (NIETZSCHE, 2014, p.22).

Então, demanda-se um currículo adequado ao "bem maior" ou um currículo que faça ovelhas criarem um modo de vida que escape às aves de rapina? Insistir no adestramento e na morte ou criar constantemente antídotos contra os inseticidas? Um currículo que negue à vida ou que afirme a vida? Provavelmente esteja havendo insistência na adequação dos anseios sociais, enquanto se poderia parar e observar o perímetro, como os ratos, as baratas e, as aves de rapina de Nietzsche.

Um currículo não vai desaparecer, e como diz Paraíso (2009, p.279), "referências são necessárias em um currículo". Desprender-se dos rebocadores pode parecer difícil e a maresia, por vezes, é vertiginosa. Um currículo não pode se munir de loucura, vagar por entre invencionices e muito menos embaralhar a "razão", mas a partir de Corazza (2003), aprende-se que vagamundar não é simplesmente sair pelo mundo errante e desviante, mas sair com o mundo a passear por entre o impensável, o intratável, porque o mundo também é movente e circula junto com a sociedade. Não se trata de pensar "outro mundo" ou um “currículo melhor", mas talvez um “currículo menor", outros modos de existência nesta 
vida que façam do currículo um lugar fora das "grades" ou, para não perder o foco, fora das "armadilhas".

Trata-se de inventar modos de existência, segundo regras facultativas, capazes de resistir ao poder bem como se furtar ao saber, mesmo se o saber tenta penetrá-los e o poder tenta apropriar-se deles. Mas os modos de existência ou possibilidades de vida não cessam de se recriar, e surgem novos (DELEUZE, 1992, p.116).

Criar é resistir. Outros modos de existência precisam ser criados, mas para isso, às vezes, é necessário fugir. Fugir, ao contrário do que se pensa, não é covardia. Trata-se de uma postura corajosa. A multidão domina as cidades, porque constitui a si mesma. Os organismos livres, singulares, não previsíveis, geram e gerem sua própria existência. E isso implica necessariamente em exposição e desvio dos inseticidas. Isso pode ser fatal, mas Nietzsche (2003) diz que é preciso ter coragem de esquecer para continuar retornando. Os desgraçados arriscam tudo perseguindo intensidades, zonas de liberdade. Fazem do caos, da clandestinidade, uma forma de vida fora do poder. Não foram cindidos da potência criadora. A vida defende-se. Ela resiste.

Recusar uma vida "maior", acostumada a abrir mão da potência, que deseja o poder, é arriscado, pois resistir ao "rebaixamento" da vida requer intensificar, movimentar a existência para além daquilo que foi dado a viver, mas "tudo que é precioso é tão difícil quanto raro" (SPINOZA, 2014, p.238). Uma vida ativa é rara. Resistir é dividir o corpo, entrar em vias de fragmentar e modificar, e não simplesmente trocar a pele. Uma produção de si mesmo.

Não se sabe como fazer o desejo se reencontrar com a potência. Talvez começando a circular nos entre cantos do concreto, construindo linhas como baratas, circulando e desertando como ratos e urubus. Movimentar outros modos de vida. Produzir enxames. "É extremamente difícil perseguir um enxame" (HARDT \& NEGRI, 2012, p. 89). Fugir, talvez, de um currículo que funciona como um inseticida tentando exterminar um modo de agir dito "destrutivo". Migrar de uma Educação Ambiental das massas, das condutas homogeneizadas, dos "corpos dóceis" como ensinou Foucault (2009) para uma Educação Ambiental da multidão, que pensa o conjunto, mas a partir das singularidades, dos rizomas. Multidão aqui não quer dizer maioria, mas multiplicidades que contrastam com a unidade indiferenciada das massas (HARDT \& NEGRI, 2012), como exposto anteriormente. 
Conceber, talvez, um currículo que incomode, que trace as linhas de resistência que o poder espreita ao mesmo tempo em que o enfrenta. Ser potência de vida resistindo ao poder sobre a vida, como pretende Pelbart (2003). Mas como se manter fiel à resistência, à insubmissão da consciência se a porta de entrada a uma política do assujeitamento é aberta? Não há recusa em se colaborar com o próprio engaiolamento social, enquanto que na ratoeira o corpo debate-se de todas as formas.

Aprender? Talvez ensinar alguma coisa que não se sabe (RANCIERE, 2002). Currículo como experiência. Como fazem os desgraçados, à medida que se esquecem e se lançam novamente ao inesperado sem a memória do ressentimento e da vingança, que faz lembrar ou incitar a fúria nos homens. Como esquecer o nojo? A bagunça que causam quando lhes atravessam com sua existência? Mas eles esquecem, são agressivos, como "uma espécie de violência positiva que se movimenta, avança, age e não deixa ser agido" (LINS, 2000). Não adoram os seres humanos como algozes, não são reféns do ressentimento que os acompanha no ensino.

Talvez, pensar no esquecimento como uma abertura, como novidade, para além de "lembrar" de que o homem é "bom ou mau”. Não haverá indignação? Sim, indignar-se é fundamental, mas não uma choraminguenta, que propaga aos quatro ventos o ressentimento, mas aquela que crie nele uma máquina de guerra contra a tristeza, o desânimo e a falta de confiança no mundo.

Perdeu-se completamente o mundo, como afirma Deleuze (2013), e, por tabela, a si mesmo. Acreditar agora é bem mais difícil, mas somente se oferece confiança ao que se lança ao novo, "mesmo que o novo ofenda o que existe" (PELBART, 2000). Será que há capacidade de construir outra memória, que não seja a de exaltar e ressentir alguma coisa? Uma memória como a do urubu, que não faz a menor ideia de que come aquilo que chamamos de inútil e ao mesmo tempo delicia-se com sua conquista. Eles prosseguem até o fim desatentos de sua insignificância ou será que não é isso que faz deles importantes e (re)conhecidos?

Devir resistência dos desgraçados, mas não aquele do George Orwell (2007) que troca um chamado déspota por outro. Trata-se de uma ação micropolítica que se faz nas fendas do concreto, nos buracos, nos esgotos, nos canos, contaminando por toda parte. 
Rompendo aquele lugar investido usualmente. Tocar as pessoas não é dizer o que elas devem fazer, mas fazer com elas, criar alianças, como aquelas que o lodo faz com a parede. Ali o padrão não existe, porque não é possível traçar um caminho, nem mesmo saber onde vai parar. Talvez seja o momento de entrar em ressonância com os madeireiros, com o capital e com tudo aquilo que é achincalhado na suposta busca do mundo melhor. Aqueles que são rejeitados têm uma potência grandiosa, porque quase sempre não estão preocupados com o tempo. Vivem o instante e produzem a partir dele ao contrário dos que se detêm nos currículo dos deveres.

Não se sabe como se constrói um espaço de experimentação do pensamento com os disparadores trágicos. Nem mesmo como pôr em prática um currículo - qualquer -coisa. $\mathrm{O}$ próprio ato da fala já é um improviso e como toda improvisação requer atenção, pois quando não há modelos ou referências é preciso redobrar o cuidado consigo mesmo.

\section{AMOR - ANTÍDOTO}

Irresponsável. Perigoso. Nojento. Desprezível. São tantos os lugares ocupados pelo homem que a tentação de melhorá-lo é imensa, diante da maledicência dos adjetivos. Impossível olhar para imagens ${ }^{1}$ nas quais o humano aparece "destruindo" a natureza e não ser prontamente julgado por aquelas palavras. Tamanha é a familiaridade com o que é visto.

Logo, o que poderá ser feito? Sensibilizar? Conscientizar? Educar? Verbos não faltam e soluções também. Nesse ponto, há unanimidade em dizer que "a terra morrerá enquanto a doença que vive nela, viver. Os humanos!”. Não fazer da vida um eterno looping de instantes ressentidos requer coragem. Será que é a isso que se reduz a vida? "Tentar mudar o mundo", o comportamento das pessoas, os hábitos e, por fim, o modo de vida para que se tenha um "mundo melhor"?

O filme "Máquinas Mortais", de Peter Jackson, uma distopia baseada no livro de Philipp Reeve, passa-se depois de um holocausto nuclear, em que a civilização humana é praticamente dizimada, dando lugar a uma nova forma de organização social. As cidades movem-se em rodas gigantes, conhecidas como "Cidades Tração", e lutam umas contra as outras para conseguir mais recursos naturais, pouquíssimos nesse cenário em que a terra está envenenada. Como toda distopia que se preze, o filme prevê um futuro apocalíptico. 
Apesar de ser um roteiro tão comum entre tantos vistos, possui uma história comovente. Ao se ler as críticas, observa-se em uma delas: "No fim das contas, é o amor que nos salva de andróides sanguinários e vingativos, e não a consciência ecológica, política e/ou social que, de fato, poderia evitar a eclosão de uma batalha apocalíptica por recursos naturais".

Na perspectiva do crítico, o amor não pode salvar o mundo, porque as pessoas são más, mesquinhas, intransigentes e tudo mais que acompanha o enredo trágico-maléficohumano. $\mathrm{O}$ amor não pode salvar um mundo em que a tecnologia que o homem manipula, constrói bombas nucleares para guerrear, paradoxalmente, é a mesma tecnologia que explora minério para criar canudinho de aço inoxidável. Possivelmente por isso que as pessoas gostem mais das distopias em que elas se transformam em zumbis. Seria mais fácil lidar com um "bestante" do que com o humano na personificação maligna. Menos pavoroso, poderia se dizer. O mais interessante em tudo isso é que o ressentimento, o medo, a morte tornaram-se lugares por excelência. No intuito de manter-se ileso a críticas morais, como uma espécie de benfeitor, luta-se contra os destruidores e imperadores do caos. Vale, Cargil, Alunorte, Agronegócio...O agro é tec, o agro é pop, o agro não poupa ninguém ${ }^{2}$.

A Educação Ambiental, especialmente nas instituições de ensino, é pensada como um aprimoramento do outro (um amor ao outro) por meio de imperativos e cartilhas de boas maneiras. Na busca da correção do homem, o "mundo melhor" foi idealizado como uma intervenção contra ele mesmo. O problema é que se fixou no que foi (antes do desmatamento) e no que será (depois do desmatamento). O tempo é, de longe, o maior desafio de uma problematização ambiental, porque uma vida livre do tempo não serve a uma demanda, não pede licença, mas não há capacidade de se ver fora desse tempo e demanda, pensados para o homem. Existem o medo da punição, do não reconhecimento e da não aceitação.

Talvez seja o momento de pensar no amor como um espaço de criação e resistência para que imagine outra Educação Ambiental. Como aquele pequeno amor-fagulha que faz incendiar o grande Amor-floresta. Mas esse amor não é aquele universal, utópico, o sonho hippiesco, e, sim um amor menor, rizomático, desengonçado. Um "amor feinho"33 como diria Adélia Prado. Será que desejaríamos um amor feinho, magro como o de Adélia? Que 
não tem nenhuma vontade de utopia? Mas empenhar no cotidiano, nos pequenos gestos, de "plantar beijos de três cores ao redor da casa" e colher miudezas na Educação Ambiental?

Diferente do amor universal, o amor pequeno, miúdo, lança-se ao mar; não quer as paisagens prontas, ditas "bonitas". Ao contrário, quer a experiência do nada, para assim inventar paisagens, dissolver as formas, traçar diferentes rotas. E quanto mais longe, mais liberto dos rebocadores, com queria Rimbaud (CAMPOS, 2002). Longe do chamado "porto seguro", possivelmente se possa livrar desse ressentimento, culpa que se concretou em nós, de modo a não nos permitir o lançamento ao mar, ao desconhecido sem estabelecer uma geografia, tornar localizável, universal. Eis porque o amor miúdo é resistência ao pessimista, pois este prefere atolar-se no ódio e no ressentimento.

O amor, se pensado como heterotopia, é o barco que escapa a toda ordem, "é o lugar sem lugar, que vive por si mesmo" (FOUCAULT, 2015). Instável e impossível. Um impossível que não é ausência, mas que mesmo materializado, não assume uma forma modelo passível de ser codificada como único. Amor - movimento. Constrói passagens, inventa uma vida itinerante fugindo dos amores totalizantes. Desterritorializa.

Veja-se o amor não como simplesmente um discurso sobre um barco no mar. Ele é um movimento que preenche o vazio do mar em contraponto ao marasmo. Fazer da Educação Ambiental um ato de amor miúdo. Capturar miudezas no mar é muito difícil. Desconsertar. Desconsolar as utopias que desejam um mundo melhor em detrimento de um mundo inquietante. Uma tarefa delicada sem dúvida, porém experimentar não é só dar conta daquilo que se denomina de ideal para a educação. O mar não dá nenhuma garantia, "não tem cabelos que a gente possa agarrar", um aparato de filtros, mas encarar o sol, demorar-se nos movimentos, sem o auxílio de mediadores.

Como lembra Larossa (2002), a experiência é o que nos acontece e não simplesmente o que acontece. Experimentar também é amar a si mesmo, ser digno do que nos acontece. Aproveitar a caminhada, não desperdiçar o instante, nem mesmo aquele que queima. O homem está diante do aprendizado, da constituição de si, mas somente consegue enxergar a injustiça na vida; o ódio no outro; a culpa em si mesmo. Aqueles lugares comuns da existência, insistentes em rodear a Educação Ambiental. 
O barco está sempre imerso na ordem do acaso e muito embora possa estar governado pelos regimes tecnológicos, não deixa de estar sujeito ao improvável, ao desconhecido. Mergulhar no desconhecido não para "descobrir o que somos, mas recusar o que somos [...] Imaginar e construir o que podemos ser" (FOUCAULT, 1995, p. 239), para além das subjetividades universalizantes que impôs aos seres humanos a recusa da individualidade e da experiência.

Ponderar sobre uma Educação Ambiental que potencialize a experiência, a vida, criando linhas de fuga, como pensa Deleuze (1998), buscando outras formas de existir, de agir quando se fala no ambiente. A ideia não é mudar os paradigmas, mas sair deles. Produzir um pensamento afirmativo; criar a própria condição da experiência, "fundar pequenos estados experimentais" (NIETZSCHE, 2004, §453).

Resistir aos amores maiores utópicos e irrealizáveis. Manter-se no mar, junto com outros barcos. Minorias no mar, certamente, porém mais potentes que os barcos atracados no porto. Navegar é dizer sim ao movimento e à vida. Passar por ventos brandos, passar por temporais e recusar o cais da eterna calmaria ${ }^{5}$.

\section{REFERÊNCIAS}

CALVINO, Ítalo. As cidades invisíveis. São Paulo: Companhia das letras, 2000.

CORAZZA, Sandra Mara; TADEU, Tomaz. Composições. Belo Horizonte: Autêntica, 2003.

CORAZZA, Sandra Mara. O drama do currículo: pesquisa e vitalismo de criação. In: Anais Encontro Nacional de Pesquisa em Educação da Região Sul, 9. Caxias do sul: UFCS, 2012.

DELEUZE, Gilles; PARNET, Claire. Diálogos. São Paulo: Editora Escuta, 1998.

DELEUZE, Gilles; GUATARRI, Félix. Mil platôs: capitalismo e esquizofrenia, vol. 3. São Paulo: Editora 34, 2012.

DELEUZE, Gilles. Conversações: 1972-1990. São Paulo: Editora 34, 2013.

FOUCAULT, Michel. Em defesa da sociedade. São Paulo: Martins fontes, 2005.

FOUCAULT, Michel. A arqueologia do saber. Rio de Janeiro: Forense Universitária, 2008. 
FOUCAULT, Michel. Vigiar e Punir: nascimento da prisão. Petrópolis: Vozes. 2009.

GALEANO, Eduardo. Séculos de conquista no lixo. Entrevista à BBC. 2012. Disponível em: http://imediata.org/?p=2228. Acesso em: 21 ago. 2019.

GALLO, Sílvio. Deleuze e a Educação. 2. Ed. Rio de Janeiro: Autêntica, 2003.

GONTIJO, Pedro Ergnaldo. Nos caminhos de uma educação por vir: ressonâncias e deslocamentos em Deleuze. Orientador: Sílvio Gallo. 2008. Tese (Doutorado em Educação) - Faculdade de Educação, Universidade Estadual de Campinas, São Paulo, 2008.

HARDT, M.; NEGRI, A. Multidão: guerra e democracia na era do Império. Rio de Janeiro: Record, 2012.

LINS, Daniel. Esquecer não é crime. In: LINS, Daniel (Org.). Nietzsche e Deleuze: intensidade e paixão. Rio de Janeiro, Relume Dumará, 2000.

NEGRI, Antonio. Kairós, Alma Venus, Multitudo: nove lições ensinadas a mim mesmo. Rio de Janeiro: DP\&A, 2003.

NIETZSCHE, Friedrich. Segunda consideração intempestiva: da utilidade e desvantagem da história para a vida. Rio de Janeiro: Relume Dumará, 2003.

NIETZSCHE, Friedrich. Genealogia da moral. São Paulo: Companhia das letras, 2004.

NIETSZCHE, Friedrich. Obras incompletas. Seleção e ensaio de Gérard Lebrum. São Paulo: Editora 34, 2014.

ORWELL, George. A revolução dos bichos. São Paulo: Companhia das Letras, 2007.

PARAÍSO, Marlucy Alves. Currículo, desejo e experiência. Educação e Realidade, v. 34, n. 2, 2009, p. 277-293.

PARAÍSO, Marlucy Alves. Diferenças no currículo. Cadernos de Pesquisa, v. 40, n. 140, 2010, p. 587-604.

PELBART, Peter Pal. Deleuze: um pensador intempestivo. In: LINS, Daniel (Org.). Nietzsche e Deleuze: intensidade e paixão. Rio de Janeiro, Relume Dumará, 2000. p. 6374.

PELBART, Peter Pal. Vida capital: ensaios de biopolítica. 2. ed. São Paulo: Iluminuras, 2009.

RANCIÈRE, Jacques. O mestre ignorante: cinco lições sobre a emancipação intelectual. Belo Horizonte: Autêntica, 2002. 
SANTOS, Igor Alexandre de Carvalho. Currículo rizomático e formação: "um pouco de possível, senão eu sufoco". Orientador: Roberto Sidnei Alves Macedo. 2014. Dissertação (Mestrado) - Faculdade de Educação, Universidade Federal da Bahia, Salvador, 2014.

SILVA, Tomaz Tadeu da. Documentos de Identidade: uma introdução às teorias de currículo. Editora Autêntica. 2005.

SPINOZA, Benedictus de. Ética. 2. ed. Belo Horizonte: Autêntica, 2014.

ŽIŽEK, Slavoj. Bem Vindo ao Deserto do Real: cinco ensaios sobre o 11 de Setembro e datas relacionadas. São Paulo: Boitempo Editorial, 2003.

\section{NOTAS}

${ }^{1}$ Comentário sobre o filme "a era da estupidez" no youtube.

${ }^{2}$ Referência à música $O$ papa é pop de Humberto Gessinger.

${ }^{3}$ Eu quero amor feinho./Amor feinho não olha um pro outro./Uma vez encontrado é igual fé,/não teologa mais./Duro de forte o amor feinho é magro, doido por sexo/e filhos tem os quantos haja./Tudo que não fala, faz./Planta beijo de três cores ao redor da casa/e saudade roxa e branca,/da comum e da dobrada./Amor feinho é bom porque não fica velho./Cuida do essencial; o que brilha nos olhos é o que é:/eu sou homem você é mulher./Amor feinho não tem ilusão,/o que ele tem é esperança:/eu quero um amor feinho. (Adélia Prado. Bagagem. Rio de Janeiro: Record, 2011. p. 97).

${ }^{4}$ Referência à música Timoneiro de Paulinho da Viola.

${ }^{5}$ Referência à música "sem companhia" de Ivor Lancellotti e Paulo César Pinheiro.

Enviado em: 10/09/2019

Aprovado em: 04/11/2019 